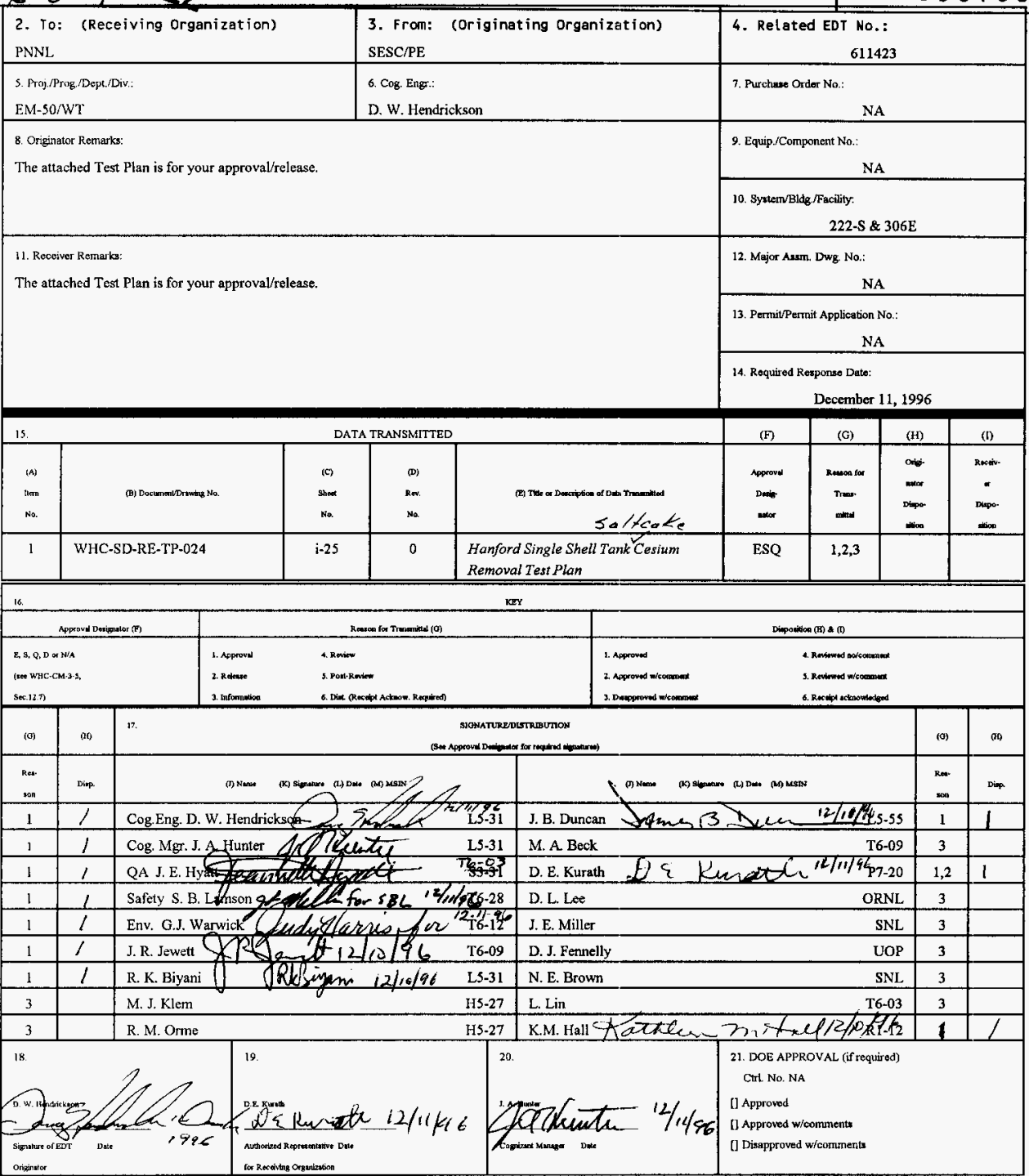




\section{Hanford Single Shell Tank Saltcake Cesium Removal Test Plan}

J.B. Duncan, D.W. Hendrickson, and R.K. Biyani

Westinghouse Hanford Company, Richland, WA 99352

U.S. Department of Energy Contract DE-AC06-87RL10930

$\begin{array}{lll}\text { EDT/ECN: } & 605798 & \text { UC: } 2020 \\ \text { Org Code: } & \text { YA40000 } & \text { Charge Code: } \\ \text { B\&R Code: } & \text { EW4010000 } 1884 & \text { Total Pages: } 31\end{array}$

Key Words: Hanford, Single She11 Tank, Tank Waste, Saltcake, Cesium, Ion Exchange, Radioactive, IE-911, Crystalline Silicotitanate

Abstract: This document provides the test preparation and conduct of a cesium removal test using Hanford Single Shell Tank Saltcake from tanks 24l-BY-110, 24l-U-108, 24l-U-109, 24l-A-101, and 24l-S-102 in a benchscale column. The cesium sorbent to be tested is crystalline silicotitanate.

TRADEMARK DISCLAIMER. Reference herein to any specific comercial product, process, or service by trade name, trademark, manufacturer, or otherwise, does not necessarily constitute or imply its endorsement, recommendation, or favoring by the United States Government or any agency thereof or its contractors or subcontractors.

Printed in the United States of America. To obtain copies of this document, contact: WHC/BCS Document Control Services, P.O. Box 1970, Mailstop H6-08, Richland WA 99352, Phone (509) 372-2420; Fax (509) 376-4989.
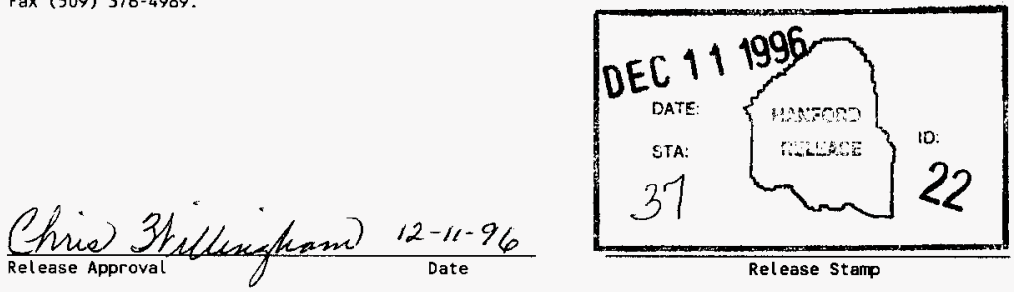

\section{Approved for Public Release}


WHC-SD-RE-TP-O24, Rev.0

THIS PAGE INTENTIONALLY LEFT BLANK 
1.0 INTRODUCTION $\ldots \ldots \ldots \ldots \ldots \ldots \ldots \ldots \ldots \ldots \ldots \ldots \ldots \ldots \ldots \ldots \ldots$

2.0 OBJECTIVE $\ldots \ldots \ldots \ldots \ldots \ldots \ldots \ldots \ldots \ldots \ldots \ldots \ldots \ldots \ldots \ldots \ldots$

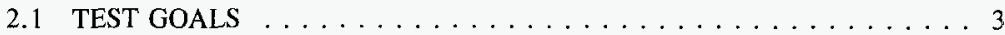

2.2 TEST CRITERIA REQUIREMENTS $\ldots \ldots \ldots \ldots \ldots \ldots \ldots$

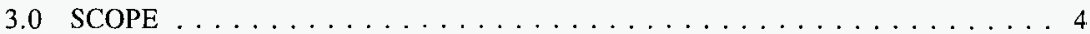

4.0 DESCRIPTION OF TEST $\ldots \ldots \ldots \ldots \ldots \ldots \ldots \ldots \ldots \ldots$

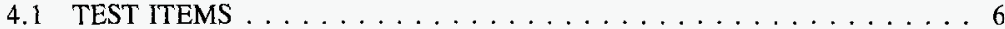

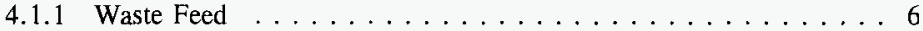

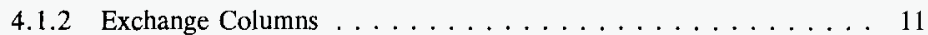

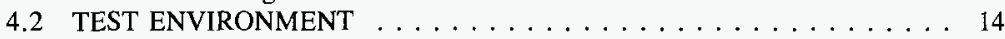

4.3 EQUIPMENT AND FACILITIES $\ldots \ldots \ldots \ldots \ldots \ldots \ldots$

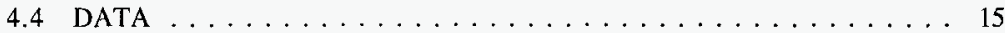

4.5 SAMPLING AND ANALYSIS $\ldots \ldots \ldots \ldots \ldots \ldots \ldots \ldots$

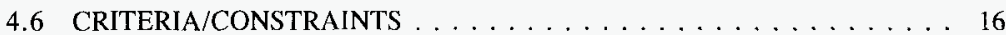

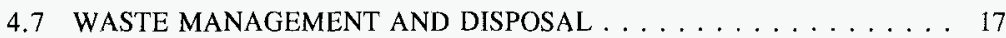

5.0 EXPECTED RESULTS $\ldots \ldots \ldots \ldots \ldots \ldots \ldots \ldots \ldots \ldots \ldots$

6.0 TEST PROCEDURE $\ldots \ldots \ldots \ldots \ldots \ldots \ldots \ldots \ldots \ldots \ldots$

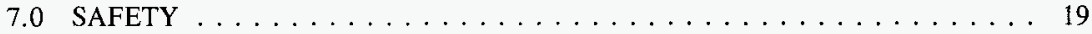

8.0 QUALITY ASSURANCE . . . . . . . . . . . . . . . . 19

9.0 ORGANIZATION AND FUNCTION RESPONSIBILITIES $\ldots \ldots \ldots \ldots$

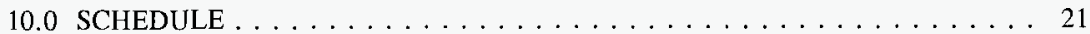

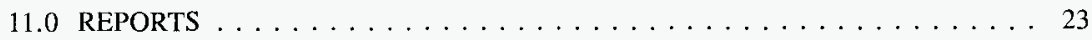

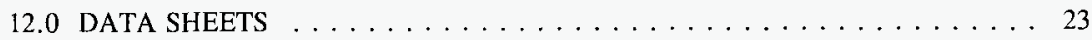

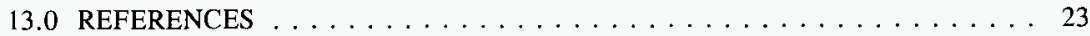


WHC-SD-RE-TP-O24, Rev.0

\section{LIST OF FIGURES}

PAGE

Figure 1: Bench-Scale Cesium Exchange Flows and Instrumentation $\ldots \ldots \ldots \ldots$ s

Figure 2: Cesium Removal Task Schedule . . . . . . . . . . . . . . . . . 22

\section{LIST OF TABLES}

PAGE

Table 1: Feed Preparation Estimates $\ldots \ldots \ldots \ldots \ldots \ldots \ldots \ldots \ldots$

Table 2: Source Waste Characterization Estimates $\ldots \ldots \ldots \ldots \ldots \ldots$

Table 3: Saltcake Core and Jar Allocations $\ldots \ldots \ldots \ldots \ldots \ldots \ldots \ldots \ldots \ldots$

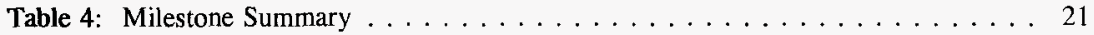


WHC-SD-RE-TP-O24, Rev.0

\section{ABBREVIATIONS}

ALARA

$\mathrm{Bq}$

$\mathrm{Ci}$

CST

CV

DF

DOE

DSSF

FDH

IX

LLW

LMHC

NHC

NRC

OST

PNNL

SESC

SST

TFA

TOC

TRU

TWRS

WHC

${ }^{137} \mathrm{mBa}$

${ }^{1.77} \mathrm{Cs}$
As low as reasonably achievable

Becquerel, one disintegration per second

Curie, $3.7 \times 10^{10}$ Becquerel

Crystalline Silicotitanate

Column Volumes

Decontamination Factor

United States Department of Energy

Double-Shell Slurry Feed

Fluor Daniel Hanford, Inc.

Ion Exchange

Low Level Waste

Lockheed Martin Hanford Corporation

Numatec Hanford Corporation

Nuclear Regulatory Commission

Office of Science and Technology

Battelle Pacific Northwest National Laboratory

SGN Eurisys Services Corporation

Single Shell Tank

Tank Focus Area

Total Organic Carbon

Transuranic, atomic number greater than 92

Tank Waste Remediation System

Westinghouse Hanford Company

Barium, metastable isotope 137

Cesium, isotope 137 
WHC-SD-RE-TP-O24, Rev.0

\section{THIS PAGE INTENTIONALLY LEFT BLANK}


WHC-SD-RE-TP-O24, Rev.0

\section{Hanford Single Shell Tank Saltcake Cesium Removal Test Plan}

\subsection{INTRODUCTION}

Cesium-137 $\left({ }^{137} \mathrm{Cs}\right)$ is a primary radiation source in the dissolved and saltcake tank waste at the Hanford Site. ${ }^{137} \mathrm{Cs}$ removal from the waste can reduce the hazard and waste classification (NRC 1989) of the low level waste and reduce treatment and disposal costs.

Several cesium removal sorbents have been developed by private industry and the U.S. Department of Energy's (DOE) Office of Science and Technology (OST) [EM-50] for the removal of cesium from the radioactive tank wastes located at various DOE facilities. In mid-1996 ion exchange column tests were conducted for evaluating cesium removal from Hanford's Double Shell Slurry Feed (DSSF) waste in tank 241-AW-101 (Hendrickson et al. 1996). There have also been a number of batch tests using Hanford tank wastes and several other column tests using simulated Hanford tank wastes or actual wastes from other DOE sites.

Hanford Site's Tank Waste Remediation System (TWRS) organization has indicated that further column-flow tests using sorbents with actual waste need to be performed to verify the applicability of the simulant data. These tests may also identify as of yet unknown problems or interferences when processing actual wastes under full-scale conditions.

The cesium sorbent which will be used for these tests is crystalline silicotitanate (CST) produced by UOP as IONSIV IE-911 ${ }^{1}$. The saltcake waste which is planned for use in this test has been sampled from Hanford Single Shell Tanks (SSTs) including 241-BY-110, 241-U-108, 241-U-109, 241-A-101, and 241-S-102.

This work is funded by the DOE OST Tanks Focus Area under Technology Task Plan RL07WT42 Cesium Flow Studies at Hanford through Pacific Northwest National Laboratory (PNNL).

\subsection{OBJECTIVE}

The overall goal of this task (test and its analysis) is to gualify a cesium sorbent challenged with Hanford Single Shell solubilized composite saltcake liquor. The specific objectives of this task to meet the goal are through test conduct and through analysis:

IONSIV and IE-911 are trademarks of the UOP, DesPlains, IL. 
The test conduct objective is to provide samples and operational data to determine the column distribution ratio (lambda, $\lambda$ ) of the sorbent when used with Hanford saltcake composite liquor in a bench-scale, column system. The column system will be operated with continuous cesium loading until breakthrough is noticeable and is increasing at a constant logarithmic rate. This will increase the validity of applying the results of previous batch and simulant tests towards the selection and design of a cesium removal system with Hanford Site tank waste.

The analytical objective is to determine whether the sorbent is able to reduce the ${ }^{137} \mathrm{Cs}$ concentration to allow subsequent manufacture of a vitrified waste form below the average concentration of $1.11 \times 10^{11} \mathrm{~Bq}{ }^{137} \mathrm{Cs}\left(<3 \mathrm{Ci} / \mathrm{m}^{3}\right)$ required by the TWRS privatization initiative (DOE 1996).

Using the specified cesium concentration limit in the vitrified waste form, the vitrification facility's liquid feed concentration is calculated in Eqn. (1). Since it does not include any cesium volatilization losses during vitrification, this is a conservatively low estimate.

For quality assurance in a pretreatment plant, the IX process effluent will probably be collected in a holding tank for batch processing. The Eqn. (1) concentration has no effect on the termination of this column test which may continue to total breakthrough of the primary column if sufficient waste feed is available. Observations throughout the test are expected to provide process data on waste/exchanger interactions, fouling, and overall loading on the sorbent.

$$
\begin{aligned}
\frac{\mu C i \mathrm{Cs}-137}{m L} & =\frac{3 \times 10^{6} \mu \mathrm{Ci}}{m^{3} \text { glass }} * \frac{m^{3} \text { glass }}{2.5 \times 10^{6} \mathrm{~g} \text { glass }} * \frac{\mathrm{g} \text { glass }}{0.25 \mathrm{~g} \mathrm{Na}_{2} \mathrm{O}} \\
& * \frac{61.98 \mathrm{~g} \mathrm{Na} \mathrm{O}_{2}}{2 \mathrm{~mol} \mathrm{Na}} * \frac{5 \mathrm{~mol} \mathrm{Na}}{1000 \mathrm{~mL} \text { waste }} \\
& =0.744
\end{aligned}
$$

Eqn. (1)

A programmatic (EM-50) objective related to this test is to make a cesium depleted effluent available to PNNL for technetium removal studies and to other Environmental Management tasks. The residual ${ }^{137} \mathrm{Cs}$ concentration is anticipated to allow follow-on technetium removal tests to be performed in a hood rather than a hot cell. 
WHC-SD-RE-TP-O24, Rev.0

\subsection{TEST GOALS}

To satisfactorily complete the objectives of the test plan, several test conduct goals must be met. The test goals are:

- Assembly, acceptance testing and placement of the sorption equipment into the hot cell.

- Hot cell receipt, solubilization, and solids removal from the tank waste feed for the sorption.

- Waste cesium removal using CST, collecting samples and data through breakthrough followed by flush of the sorption material.

Appropriate and safe waste and material disposition.

\subsection{TEST CRITERIA REQUIREMENTS}

The assembly, acceptance testing and placement criterion of the test will be considered complete when all sorption, sampling, and detection equipment has been acquired, assembled, leak tested, calibrated, and placed into the hot cell with flow path and valve operation confirmed.

The second criterion will be complete when the required masses of radioactive saltcake samples from Hanford SSTs 241-BY-110, 241-U-108, 241-U-109, 241-A-101, and 241-S-102 are acquired from analytical storage, transferred to the hot cell, solubilized, mixed, settled, and centrifuged or filtered for solids removal as needed. The solubilized waste will then be stored in appropriate feed $\operatorname{tank}(\mathrm{s})$, and sampled and analyzed for initial feed characterization confirmation.

The third criterion will be considered complete when the CST test and backup columns have been placed in the test apparatus (in concert with the CST guard columns), prepared for contact, contacted with the waste feed flow through breakthrough (beyond $50 \%$ effluent/feed concentration, $\mathrm{C} / \mathrm{C}_{0}{ }^{137} \mathrm{Cs}$ ) and the system and sorption material flushed. Sample and data acquisition is required during the cesium removal. Sample analysis is required during or following the cesium removal.

The final criterion will be considered complete when waste feed materials, contaminated equipment, effluents, flushes, and exchange materials have been appropriately characterized and are dispositioned for appropriate disposal or reuse. 


\subsection{SCOPE}

The scope of this test plan includes the acceptance and process testing of a bench-scale cesium exchange equipment array with radioactive Hanford tank waste feed material. The acceptance and process testing will include: waste feed analysis and preparation, exchange bed preparation, exchange, the acquisition and analysis of samples and data from the exchange, exchange bed flush, waste and material disposition. Physical property, chemical, and radiochemical analysis of sample materials, although directed by this plan, are within the scope of routine sample analysis and not proceduralized herein.

This test plan is to be executed under the direction of the SGN Eurisys Services Corporation's Process Engineering (PE) staff in coordination with and by the staffs of Fluor Daniel Hanford Inc. (FDH) and their subcontractors Numatec Hanford Corporation (NHC), Lockheed Martin Hanford Corporation (LMHC), and Rust Federal Services Hanford Inc. (RFSH). The test work is to be conducted within the facilities and hot cells of the 222-S Analytical Laboratory.

\subsection{DESCRIPTION OF TEST}

For this cesium ion exchange test, a test apparatus will be constructed, leak tested, then placed in a hot cell within the 222-S Laboratory. Approximately $3 \mathrm{Kg}$ of Hanford SST saltcake will be used to yield approximately $6.2 \mathrm{~L}$ of saltcake solution with a target of five molar sodium. Dependent upon performance of the sorbent, additional mass of saltcake may be used. The solution will be mixed, settled and decanted to remove particles, filtered as necessary and then placed in the feed tank(s) to be used as the influent for the column test.

The test apparatus will contain one primary test column, a backup test column, and two scavenging (guard) columns. All test columns will be packed with granular crystalline silicotitanate (CST). The CST used will be either the most recently available production batch or that used in recent testing (Hendrickson et al. 1996). The scavenging columns will be used to reduce the concentration of cesium remaining in the effluent. The effluent is intended to be provided to subsequent Tanks Focus Area (TFA) tasks which will require the material for technetium $(\mathrm{Tc})$ removal studies. A sketch of the process flows and instrumentation is provided in Figure 1. Specific test instructions will be provided in another document. 


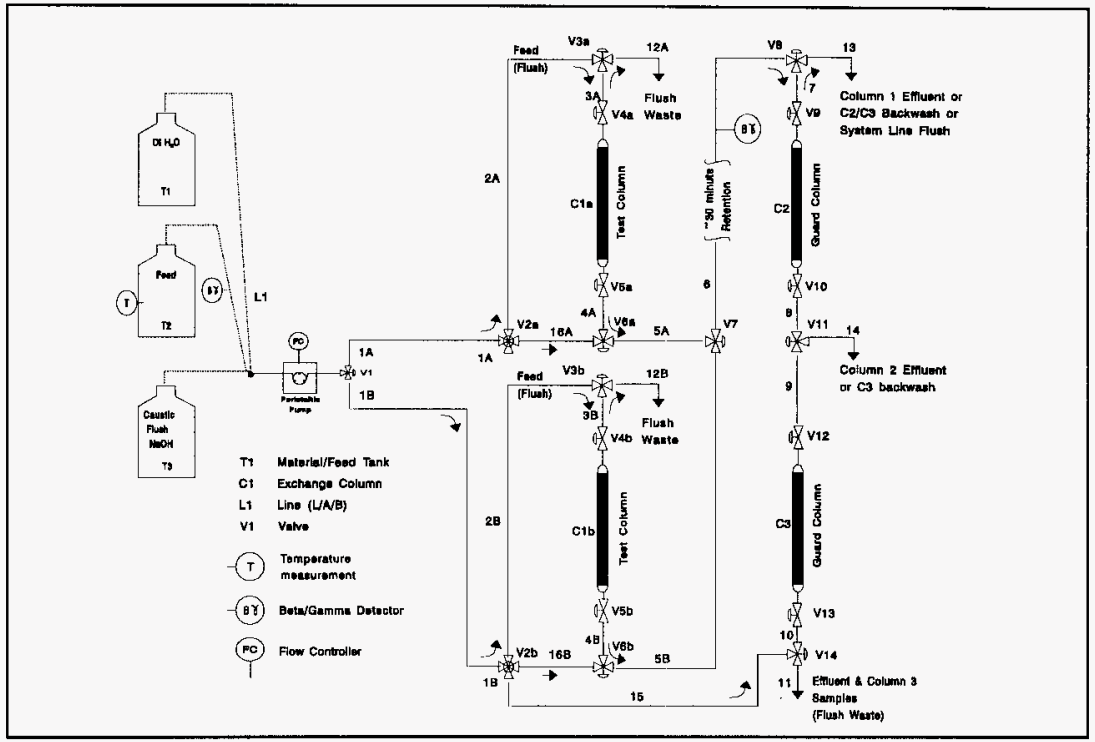

Figure 1: Bench-Scale Cesium Exchange Flows and Instrumentation

During the loading phase of the column test, the feed solution will be pumped from the feed tank downward through a test column of cesium sorbent. The feed temperatures will be recorded at the beginning, during, and after the test. The effluent will be continuously monitored for cesium breakthrough with a beta-gamma probe and will be sampled periodically for wet chemistry analysis. Samples will also be taken of the feed liquid. Sample analysis will be performed to determine the concentration of analytes to which the cesium ion exchange and vitrification processes are sensitive. These analytes may include: cesium-137, total cesium, strontium, sodium, potassium, rubidium, aluminum, phosphorus (for phosphate), chromium, TOC, and iron as well as the $\mathrm{pH}$ of the sample.

After cesium breakthrough is detected in the CST test column, the CST column will be flushed and drained. Initial disposal plans for the cesium sorbent materials are in-cell digestion and disposal due to the high shielding requirements and limited capacity of manipulators and airlock tray entailed with removal from the hot cell (see $\S 4.7$ ). 
The performance of the sorbent in the removal of cesium from saltcake, and process considerations of such removal, will be evaluated and reported in a final report.

\subsection{TEST ITEMS}

The test items are the bed material (CST) and the waste feed. The object of this test is to demonstrate the cesium selectivity and load capacity of CST using actual Hanford saltcake waste. In reporting the completion of this work, this information will be compared to related data gathered using simulants and other actual wastes and will be used to validate the simulant data's use in the design of a cesium removal pretreatment process.

\subsubsection{Waste Feed}

For estimating the waste volume needed for this test, the prior characterization knowledge of the waste, dilution requirements, and additional estimates of the waste source and history are important parameters.

\subsubsection{Volumetric and Source Requirements}

The waste mass required for adequate demonstration of the performance of these columns is estimated to be $5 \mathrm{Kg}$ (to be diluted to approximately 11 liters). This is based on a final feed concentration of approximately $5 \underline{\mathrm{M}}$ sodium and $0.5 \mathrm{M}$ hydroxide (Table 1 ).

The waste feed is to be a dissolution of Hanford Single Shell saltcake wastes. It is anticipated that the saltcake from U-108 will comprise a significant portion (if not all) of the feed. The estimated feed preparation requirements per liter of waste liquor are guided by current tank farm tank and pipeline composition specifications. These specifications (OSD-T-151-00007, 7.2) require that acceptable materials with nitrate concentrations between 1.0 and $3.0 \mathrm{M}$, must have hydroxide of at least $10 \%$ that of nitrate with a combined hydroxide and nitrite concentration of at least $40 \%$ that of the nitrate. Liquor compositions

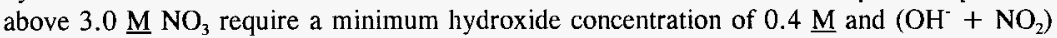
$>1.2 \mathrm{M}$. In this case, addition of caustic as indicated in Table 1 would yield a product stream which will meet tank farm specifications. This is the assumed waste feed for this test.

With the caustic addition, the cesium concentration in the waste will decrease. Previous experience (Hendrickson, Biyani, Beck 1996) with this CST material and DSSF 241-AW-101 waste has led to the formulation of a tentative model of sorbtion performance as described in Eqn. (2). With prior mean cesium concentrations of $216 \mu \mathrm{Ci} / \mathrm{mL}, 50 \%$ and $70 \%$ breakthroughs would be modeled to require 14,100 and 17,900 column volumes of flow (40 and $48.2 \mathrm{~L}$ of feed -12.4 to $15.8 \mathrm{~L}$ of tank saltcakes). Due to the low potassium content of 
this waste, it is considered reasonable that the cesium loading will be higher. Ancillary analyses by CST developers and researchers at Sandia National Laboratory indicate that as few as 910 column volumes of this feed may be necessary to achieve $50 \%$ breakthrough. In the manner of a Freundlich isotherm, at very low concentrations of cesium in the liquor, the equilibrium, and flow based, sorbent surface concentration is expected to be low. As such, waste needs are a minimum of $980 \mathrm{~g}$ with a target of $4,900 \mathrm{~g}$. Test procedures must remain capable of providing dissolved feeds if treatment volumes, in conduct, appear to exceed this mass target.

Eqn. (2)

$$
\frac{C}{C_{0}}=\frac{1}{a+b e^{-c x \frac{[C]^{\prime}}{[C]}}}
$$

where: $\quad a=1.3285, \quad b=832.6402, c=0.0104, X=$ Column Volumes of Flow $[C]^{\prime}=$ New Cs -137 Concentration, $[C]=$ Tested $C s-137$ Concentration with solution for defined breakthrough: $X=\frac{\ln \left(\frac{\frac{C_{0}}{C}-a}{b}\right)}{-c} \frac{[C]}{[C]^{\prime}}$ 
WHC-SD-RE-TP-O24, Rev.0

Table 1: Feed Preparation Estimates

\begin{tabular}{|l|r|r|r|r|r|}
\hline \multicolumn{7}{|c|}{ Feed Material Estimates (/L Source Material) Mole or Ci/L } \\
\hline Tank & $241-\mathrm{BY}-110$ & \multicolumn{1}{|c|}{$241-\mathrm{U}-108$} & $241-\mathrm{U}-109$ & $241-\mathrm{A}-101$ & \multicolumn{1}{c|}{$241-\mathrm{S}-102$} \\
\hline Density $(\mathrm{g} / \mathrm{mL})$ & 1.17 & 1.20 & 1.23 & 1.23 & 1.25 \\
\hline $\mathrm{OH}$ & 0.50 & 0.50 & 0.50 & 0.50 & 0.50 \\
\hline $\mathrm{Na}$ & 5.00 & 5.00 & 5.00 & 5.00 & 5.00 \\
\hline $\mathrm{Al}$ & 0.228 & 0.000 & 0.000 & 0.445 & 0.274 \\
\hline $\mathrm{Cr}$ & 0.024 & 0.000 & 0.000 & 0.031 & 0.028 \\
\hline $\mathrm{K}$ & 0.022 & 0.014 & 0.000 & 0.040 & 0.012 \\
\hline $\mathrm{NO3}$ & 1.999 & 3.607 & 3.506 & 3.955 & 3.187 \\
\hline $\mathrm{NO} 2$ & 0.528 & 0.891 & 0.992 & 1.589 & 0.811 \\
\hline PO4 & 0.065 & 0.000 & 0.000 & 0.022 & 0.253 \\
\hline $\mathrm{SO} 4$ & 0.084 & 0.000 & 0.000 & 0.132 & 0.051 \\
\hline $\mathrm{CO} 3$ & 1.157 & 0.000 & 0.000 & 0.000 & 0.237 \\
\hline $\mathrm{Cs}-137$ & 0.0262 & 0.0553 & 0.0559 & 0.1041 & 0.0670 \\
\hline Sr-90 & 0.0098 & 0.0000 & 0.0000 & 0.0000 & 0.0115 \\
\hline $\mathrm{Na} / \mathrm{Cs}-137$ & $2,262,333$ & $1,070,302$ & $1,060,374$ & 569,250 & 884,728 \\
\hline $\mathrm{Na} / \mathrm{K}$ & 232 & 357 & $\mathrm{NA}$ & 124 & 422 \\
\hline Diluent NaOH $\mathrm{M}$ & 0.718 & 0.636 & 0.676 & 0.694 & 0.749 \\
\hline Final Volume (1) & 3.30 & 4.67 & 3.84 & 3.58 & 3.01 \\
\hline
\end{tabular}

\subsubsection{Tank Characterization History}

Prior knowledge of the waste composition has been applied in preparing this test plan. The most recent analyses are presented in Table 2 . This material is used as a source because it well represents the bulk of saltcake wastes at Hanford. The ready availability of these samples in the 222-S laboratory eliminates added sampling costs and expedites testing. 
Table 2: Source Waste Characterization Estimates

\begin{tabular}{|l|r|r|r|r|r|}
\hline \multicolumn{7}{|c|}{ Source Characterization (balanced for charge) Mole or Ci per L } \\
\hline Tank & $241-\mathrm{BY}-110$ & $241-\mathrm{U}-108$ & $241-\mathrm{U}-109$ & $241-\mathrm{A}-\mathrm{I} 01$ & $241-\mathrm{S}-102$ \\
\hline Density $(\mathrm{g} / \mathrm{mL})$ & 1.44 & 1.74 & 1.75 & 1.70 & 1.64 \\
\hline $\mathrm{OH}$ & 0 & 0 & 0 & 0 & 0 \\
\hline $\mathrm{Na}$ & 14.845 & 21.003 & 17.254 & 16.117 & 13.554 \\
\hline $\mathrm{Al}$ & 0.753 & 0.000 & 0.000 & 1.592 & 0.827 \\
\hline $\mathrm{Cr}$ & 0.080 & 0.000 & 0.000 & 0.111 & 0.084 \\
\hline $\mathrm{K}$ & 0.071 & 0.065 & 0.000 & 0.145 & 0.036 \\
\hline $\mathrm{NO3}$ & 6.596 & 16.837 & 13.445 & 14.162 & 9.599 \\
\hline $\mathrm{NO} 2$ & 1.740 & 4.160 & 3.804 & 5.691 & 2.442 \\
\hline $\mathrm{PO} 4$ & 0.215 & 0.000 & 0.000 & 0.080 & 0.762 \\
\hline $\mathrm{SO} 4$ & 0.276 & 0.000 & 0.000 & 0.473 & 0.153 \\
\hline $\mathrm{CO} 3$ & 3.815 & 0.000 & 0.000 & 0.000 & 0.714 \\
\hline $\mathrm{Cs}-137$ & 0.0864 & 0.2584 & 0.2143 & 0.3728 & 0.2017 \\
\hline $\mathrm{Sr}-90$ & 0.0324 & 0.0000 & 0.0000 & 0.0000 & 0.0348 \\
\hline $\mathrm{Na} / \mathrm{Cs}-137$ & $2,036,100$ & 963,249 & 954,311 & 512,337 & 796,252 \\
\hline $\mathrm{Na} / \mathrm{K}$ & 209 & 321 & $\mathrm{NA}$ & 111 & 380 \\
\hline
\end{tabular}

Tank waste by core and jar to be applied in the test are identified in Table 3. Portions that appear below the highlighted cells are identified as available, but they are not anticipated to be used. Waste salts will be used sequentially in the primary test conduct. The sequence of waste salts, by jar are provided in Table 3, top to bottom, left to right. In the event that the backup lead column is used to treat additional salts after planned conduct with Table 3 wastes and salts from 241-A-101 have not yet been used, the 241-A-101 salts to the limit of 1,750 g may be used in salt cesium treatment. 
Table 3: Saltcake Core and Jar Allocations

\begin{tabular}{|c|c|c|c|c|c|c|c|c|c|c|c|}
\hline \multicolumn{12}{|c|}{ Saltcake Core And Jar Allocations For Feed Material } \\
\hline Tank & $241-U-108$ & \begin{tabular}{|l|} 
Parent \\
\end{tabular} & 1480.6 & Tank & $241-U-109$ & Parent & 1721.5 & Tank & $241-A-101$ & Parent & 1758.22 \\
\hline Core & Segment & Jar & Mass & Core & Segment & Jar & Mass & Core & Segment & Jar & Mass \\
\hline 146 & $5-U$ & 10019 & 221.3 & 123 & 4 & 8831 & 195.7 & 156 & $6-U$ & 11077 & 106.09 \\
\hline 141 & $6-\mathrm{L}$ & 9834 & 156 & 123 & 2 & 8834 & 186.4 & 154 & 7-L & 10566 & 102.2 \\
\hline 146 & $6-\mathrm{U}$ & 10188 & 147.1 & 123 & $7-\mathrm{U}$ & 8847 & 140.3 & 154 & $9-\mathrm{L}$ & 11165 & 97 \\
\hline 145 & $7-U$ & 10088 & 139.6 & 123 & $6-\mathrm{U}$ & 8839 & 132.2 & 156 & $7-\mathrm{U}$ & 10611 & 96.36 \\
\hline 141 & 5-L & 9839 & 122.4 & 123 & $6-\mathrm{L}$ & 8840 & 126.8 & 154 & $4-U$ & 11079 & 92.62 \\
\hline 146 & $6-\mathrm{L}$ & 10189 & 121 & 124 & $5-U$ & 8844 & 125.1 & 156 & $3-\mathrm{U}$ & 10615 & 91.28 \\
\hline 145 & $8-U$ & 10018 & 118.2 & 124 & 6-L & 8845 & 121.1 & 154 & $7-\mathrm{U}$ & 10572 & 90.6 \\
\hline 146 & $8-U$ & 10092 & 116.1 & 124 & 4 & 8841 & 111.9 & 156 & 4-U & 11076 & 90.47 \\
\hline 146 & 7-L & 10182 & 115.8 & 124 & $7-\mathrm{U}$ & 8853 & 109.4 & 156 & $5-\mathrm{L}$ & 10628 & 88.3 \\
\hline 141 & $9-\mathrm{U}$ & 10014 & 111.8 & 124 & $6-U$ & 8846 & 100.5 & 154 & $3-U$ & 11068 & 86.7 \\
\hline & & & & 124 & $8-U$ & 8856 & 100.2 & 156 & 4-L & 11078 & 85.09 \\
\hline 141 & $6-\mathrm{U}$ & 9838 & 111.3 & 124 & 3 & 8842 & 95.3 & 156 & $8-\mathrm{U}$ & 10631 & 83.65 \\
\hline 146 & $7-\mathrm{U}$ & 10181 & 107.1 & 124 & 8-L & 8854 & 89.5 & 156 & $3-\mathrm{L}$ & 10620 & 81.45 \\
\hline 146 & $3 \mathrm{~A}$ & 10021 & 107.1 & 124 & $5-\mathrm{L}$ & 8843 & 87.1 & 154 & 4-L & 11070 & 77.61 \\
\hline 141 & $5-\mathrm{U}$ & $\begin{array}{l}9837 \\
\end{array}$ & 106.8 & & & & & 154 & 6-L & 11167 & 75.47 \\
\hline 146 & 8-L & 10200 & 106.4 & 124 & 7-L & 8849 & 74.8 & 154 & 6-U & 11169 & 74.54 \\
\hline 145 & $6-U$ & 9993 & 102.28 & 123 & 9-B & 8852 & 73.7 & 154 & 3-L & 10626 & 72.9 \\
\hline 145 & $8-\mathrm{L}$ & 10011 & 96.9 & & & & & 156 & 5-U & 10612 & 70.3 \\
\hline 145 & 6-L & 10012 & 96.5 & & & & & 154 & $2-\mathrm{L}$ & 11073 & 66.13 \\
\hline 145 & $5-U$ & 10047 & 95.27 & & & & & 156 & 6-L & 11072 & 65.12 \\
\hline 146 & 5-L & 10020 & 87 & & & & & 156 & 8-L & 10630 & 64.34 \\
\hline 145 & 7-L & 10049 & 86.4 & & & & & & & & \\
\hline 145 & 5-L & 10087 & 75.72 & & & & & 154 & 9-U & 11166 & 57.6 \\
\hline 145 & $4-U$ & 10045 & 62.9 & & & & & 154 & COMP & 11562 & 50.8 \\
\hline 145 & 9-U & 10183 & 60.3 & & & & & 156 & 7-L & 10974 & 27.97 \\
\hline 145 & $3-U$ & 10052 & 51.3 & & & & & 154 & 19-L & 10973 & 27.21 \\
\hline 145 & $2-U$ & 10030 & 49.97 & & & & & 156 & $10-\mathrm{U}$ & 11074 & 22.94 \\
\hline 145 & 4-L & 10048 & 47.4 & & & & & & & & \\
\hline 146 & $4-\mathrm{U}$ & 10032 & 42 & & & & & & & & \\
\hline 145 & 3-L & 10033 & 35.7 & & & & & & & & \\
\hline
\end{tabular}

The cesium concentration in saltcake solutions is from one-half to one-tenth that of previously tested DSSF waste, and comprises a new area of CST investigation with actual wastes. However, in case the cesium loading to $50 \%$ breakthrough in this test is found to be 
under $1000 \mathrm{CV}$, cesium removal with CST may not prove to be economical for Hanford saltcake. This will be addressed in a final test report.

TRU contaminants in the waste and their sorption must be considered for waste designation and appropriate disposal.

\subsubsection{Dilution Capability and Requirements}

As described above, the waste feed of the targeted tanks ranges from approximately 13.5 $\mathrm{M} \mathrm{Na}^{+}$to approximately $21.0 \mathrm{M} \mathrm{Na}{ }^{+}$with no reported free hydroxide. In order to facilitate performance and minimize degradation of the exchange materials, the waste feed will be diluted to a target of approximately $5.0 \underline{\mathrm{M}} \mathrm{Na}$. The diluent, in prior work for similar wastes (Brown et al. 1995), was aqueous sodium hydroxide so that gibbsite $\left(\mathrm{Al}(\mathrm{OH})_{3}\right)$ precipitation would not occur $\left(\mathrm{OH}^{-}\right.$falling below $\left.\sim 2 \mathrm{M}\right)$. Investigations of sodium aluminate, sodium sulfate, sodium carbonate, sodium nitrite, and sodium nitrate solubility (Barney 1976), as applied to this waste composition, indicate that each of these constituents would remain in solution at expected temperatures with solubilization with approximately $0.75 \mathrm{M}$ caustic solution.

\subsubsection{Waste Composition Estimates}

During prior work, the overall cesium loading and competition was not readily available. It was estimated (Hendrickson and Duncan 1996) that cesium-137 accounted for 22.8 mole \% of total cesium and that rubidium represented 19 mole \% that of cesium. Analyses on 241-AW-101 wastes confirmed a cesium-137 composition of $\sim 21.5 \%$. For the purposes of this test plan these analyses and assumptions will continue.

In total, the target counter-ion for the exchange $\left({ }^{137} \mathrm{Cs}\right)$ is estimated to represent approximately $20 \%$ of the total cesium and rubidium present in the waste.

\subsubsection{Exchange Columns}

The test apparatus will operate as an assembly of a primary, a backup primary (should early fouling occur or should the opportunity arise to repeat the experiment) and two guard columns packed with CST. For ease of construction, disposal, and process observation, the columns will be fabricated of glass.

During the loading phase of the column test, the feed solution will be pumped from the feed tank downward through a test column of cesium sorbent. The effluent will be monitored for cesium breakthrough and will be sampled periodically. After passing through the test column, the effluent will pass through two cesium scavenging column to capture most of the 
residual cesium and then flow into the effluent tank. This loading phase is planned to be continued, beyond $50 \%$ cesium breakthrough, to near total CST depletion in the test column, subject to process or feed solution quantity limitations.

The waste from the flushes will be sent to a waste tank for disposal. After the sorbent columns are tested, the apparatus will be washed out with $0.5 \underline{\mathrm{M} \mathrm{NaOH}}$, and disposed as waste.

The effluent from the test will be retained and provided for subsequent Tanks Focus Area (TFA) tasks which will require the material for technetium (Tc) removal studies.

Periodic samples will be taken of the test column effluent during the loading phase. Samples will also be taken of the feed. Sample analyses will be performed to determine the concentration of analytes to which the cesium ion exchange and vitrification processes are sensitive. These analytes include: cesium-137, total cesium, strontium, sodium, potassium, rubidium, aluminum, phosphate, chromium, iron and total organic carbon (TOC).

Should the opportunity arise for experimental repetition, test procedures and instructions will be revised to include use of the backup primary column in the contact with a different saltcake waste. Primary sampling will be accomplished using the on-line gamma detection. The basis for experimental repetition requires that neither lead column has fouled and the applicable lead column has not been contacted with waste and that prior performance of CST with saltcake provides sufficient reason to believe that not more than $1.75 \mathrm{~kg}$ of the second saltcake would be required to yield greater than $50 \%$ break through of ${ }^{137} \mathrm{Cs}$.

The performance of the sorbents in the removal of cesium from saltcake waste, and process considerations of such removal, will be evaluated and reported in the final report.

\subsubsection{Theory and Mechanisms of Ion Exchange}

For the purpose of understanding the basis for test actions, a brief description is provided herein of the bases for cesium separation with the test material.

An ion exchange reaction is a reversible interchange of ions between a solid phase and a solution (Harland 1994). In the conduct and performance analysis of ion exchange, it is customary to determine the distribution coefficient $D_{i}$ (Marinsky and Marcus 1995), also referred to as $\mathrm{K}_{\mathrm{d}}$.

$$
D_{t}=\frac{\text { concentration of solute in exchanger }}{\text { concentration of solute in solution }} \equiv\left|\frac{\frac{g \text { solute }}{g \text { dry exchanger }}}{\frac{g \text { solute }}{\text { volume solution }}}\right|
$$


WHC-SD-RE-TP-O24, Rev.0

When considering the separation of different ions, the ratio of distribution coefficients of two different ions $\mathrm{A}^{+}$and $\mathrm{B}^{+}$is the separation factor $\alpha_{\mathrm{A} / \mathrm{B}}$,

$$
\alpha_{A / B}=\frac{D_{A}}{D_{B}}
$$

In general, if $\alpha_{\mathrm{A} / \mathrm{B}}$ is $>1$, ions $\mathrm{A}$ are more selectively removed from the solution to the ion exchanger than are ions B. Thus, $\alpha_{\mathrm{A} / \mathrm{B}}$ is also termed the selectivity of the exchange material. Series of studies may yield selectivity series (e.g. $\mathrm{Na}<<\mathrm{K}<\mathrm{Cs}<\mathrm{Rb}$ ). These selectivities will be based upon a number of parameters of the exchange, including whether the exchange is through organic or inorganic media.

\subsection{Inorganic Exchange Media}

In inorganic cationic exchange, if an ion exchanger $\mathrm{M}^{-} \mathrm{A}^{+}$, carrying cations $\mathrm{A}^{+}$as the exchanger ions, contacts an aqueous solution containing $\mathrm{B}^{+}$cations, an ion exchange reaction occurs and may be represented as:

$$
\underset{\text { Solid }}{M^{-} A^{+}}+\underset{\text { Solution }}{B^{+}} \rightleftharpoons \underset{\text { Solid Solution }}{M^{-} B^{+}}+A^{+}
$$

In the cation exchange equilibrium represented in Eqn. (5), $\mathrm{M}^{-}$is the insoluble fixed anionic complement of the ion exchanger $\mathrm{M}^{-} \mathrm{A}^{+}$, called the fixed anion. The cations $\mathrm{A}^{+}$and $\mathrm{B}^{+}$ are counter-ions, while other ions in the solution with the same charge as the fixed anion are called co-ions.

In the cesium ion exchange test with crystalline silicotitanate, prior to the test execution, the media will be conditioned with sodium hydroxide. The hydroxide ion $\left(\mathrm{OH}^{-}\right)$plays the $\mathrm{A}^{+}$ part in Eqn. (5), The $\mathrm{B}^{+}$part in the equation is played by the counter-ions of $\mathrm{Li}^{+}, \mathrm{Na}^{+}$, $\mathrm{K}^{+}, \mathrm{Rb}^{+}$, and $\mathrm{Cs}^{+}$. The extent to which one of these cations is more greatly exchanged with the substrate fixed anion than another counter-ion is termed the selectivity. Primary determining factors in selectivity in inorganic ion exchange include: concentration of the exchanging ions, crystallinity of the materials, and solution media and ionic strength.

With regard to crystallinity, for exchange to take place, the cation in the solution must diffuse through the 'windows' connecting cavities in the crystal lattice. When the window is smaller than the diameter of the hydrated counter-ion, part or all of the water molecules of the hydration shell must be lost to allow the cation to pass a window and approach an 
exchange site. If cations can only pass these windows with the loss of water molecules, the kinetic effects of the reaction will be dependent upon the hydration energies of the various ions. Further, if the counter-ions have larger crystal ionic radii than the opening of the window, the capture effect seen is that of an ion sieve.

An overall description of this effect is that the charge of the fixed anion is sufficient to draw a counter-ion through a window, stripping it of waters of hydration. Once inside the cavity, the material is slowed in exit by its hydrated radius relative to the window and the energy requirement to shed additional water molecules in order to escape.

Based upon the crystal ionic radii, it was theorized in a recent cesium removal test plan (Hendrickson and Duncan 1996), that the meta-stable barium-137 in secular equilibrium with the cesium-137 would be significantly more likely to pass through the crystal lattice window to the bulk solution and exit the exchange bed. However, parametric analysis with a betagamma in-line probe, performed during subsequent test conduct (Hendrickson et al. 1996) has indicated that the meta-stable barium- 137 formed on the exchanger sites was not being released at any levels detectable above background.

\subsubsection{Crystalline Silicotitanate Exchange Column}

The CST column for the cesium exchange test is to be constructed of glass, with a circular cross-section, an internal diameter of $0.7 \mathrm{~cm}$, and packing height of $7 \mathrm{~cm}$. The CST exchange material is an inorganic material designed and fabricated to control crystal lattice spacing such that cesium is selectively captured within the structure. It has been chosen for this test following other investigations of selectivity and loading with simulated wastes (Bray et al. 1993). The duplicate primary columns (Figure 1, C1a \& C1b) will be packed with an engineered form of CST. The scavenging columns (Figure 1, C2 \& C3), also to be packed with CST, are anticipated to be of $1 \mathrm{~cm}$ diameter and packing height of $10 \mathrm{~cm}$. All columns will be operated with $10 \mu \mathrm{m}$ bed supports/filters.

- CSTs have been developed by scientists at Texas A\&M University and the Sandia National Laboratory (SNL) and produced by UOP as IONSIV, IE-911. The CST material to be used in this test is to be acquired from UOP. The final report will include material batch information for the exchange material.

After test completion the CST columns will be flushed with $0.15 \mathrm{M} \mathrm{NaOH}$.

\subsection{TEST ENVIRONMENT}

The test environment is primarily that of the RFSH and NHC operated 222-S analytical laboratories. 
During assembly and acceptance testing of the exchange equipment, assembly is largely anticipated to occur in the 306E laboratories (300 Area) and acceptance testing in nonradiological portions of the $222-S$ laboratories. The exchange equipment will be placed into a high-radiation hot cell (probably lF) of the 222-S laboratory where the process tests will occur.

Waste material samples are currently present within radioactive sample storage at the 222-S laboratory. Applied materials will be placed inside the hot cell used for the test work.

With the exception of sample analyses at the 222-S laboratory or the Battelle Pacific Northwest National Laboratory 325 laboratory, the remainder of work will be done within hot cells at 222-S.

\subsection{EQUIPMENT AND FACILITIES}

Equipment needed for the apparatus assembly and test conduct will be detailed in test procedures being developed. Such equipment includes: exchange columns, tubing, valves, a peristaltic pump, CST exchange material, a beta-gamma detector probe and data collection system, sample vials, and feed and collection containers.

Reagents required include deionized water, aqueous solutions of sodium hydroxide, hydrochloric acid, hydrofluoric acid, and tank waste saltcakes from 241-BY-110, 241-U-108, 241-U-109, 241-A-101, and 241-S-102. Saltcake tank waste mass needs are approximately $5 \mathrm{~kg}$ (to be solubilized to approximately 11 liters) .

Facilities required are those of the $222-\mathrm{S}$ laboratory $(1 \mathrm{~F})$ hot cell, and non-radiological portions of 222-S (building 222-SA) and 306E for equipment assembly and acceptance testing.

\subsection{DATA}

Parameters to be measured, and the precision required is, in large part, defined by the test subtask. In general, the parameters of measurement, when not in chemical assay, are those of interval, volume, mass, and beta/gamma decay measurement. The subtasks to be described herein, and executed per test procedures and instructions, are waste feed preparation, exchange column packing, conditioning, flush, operation, sampling, and waste material handling. Chemical assay quality assurance is described in $\S 8.0$. Data acquisition and handling particular to this test will be in consonance with the Quality Assurance Plan for laboratory process tests (Meznarich 1996). 
WHC-SD-RE-TP-O24, Rev.0

\subsection{SAMPLING AND ANALYSIS}

The effectiveness of the CST sorbent in cesium removal will be monitored on-line with the beta-gamma probe. These probe counts, displayed on a screen, will be the primary means of detecting breakthrough and subsequently determining termination of the flow test. The reliability of this method of monitoring effluent cesium concentration has been demonstrated in Hendrickson, Biyani and Beck (1996).

In addition to the on-line probe data, periodic samples of the test column effluent will be taken for analyses by wet chemistry methods. Samples will also be taken of the feed, separated feed solids, first guard column effluents, and composite second guard column effluents. Sample analyses will be performed to determine the concentration of analytes to which the cesium ion exchange and vitrification processes are sensitive. These analytes include: cesium-137, total cesium, strontium, sodium, potassium, rubidium, aluminum, phosphate, chromium, iron, and total organic carbon (TOC) as well as the $\mathrm{pH}$.

Sample analyses to be detailed in test procedures include chemical and radiochemical analyses of waste feed batches, primary, and secondary column effluent and composite (post guard column) effluent samples, and dissolved IX materials. Analytical methods, dependent upon need, matrix and funding, are planned to include inductively coupled plasma mass spectroscopy (ICP-MS), inductively coupled plasma-atomic emission spectroscopy (ICP-AES), gamma energy analysis (GEA), total alpha analysis, beta scintillation (Tc and $\mathrm{Sr}$ ), $\mathrm{OH}^{-}$specific ion electrode (SIE) analysis, suspended solids, and TOC.

\subsection{CRITERIA/CONSTRAINTS}

The nature of this test is that of a treatability test. As such, the activities encompassed within this test are governed by WAC 173-303-071(3)(r) [Treatability Study Samples] and WAC 173-303-071(3)(s) [Samples undergoing treatability studies at laboratories and testing facilities] thereby generating a requirement that the Washington State Department of Ecology (WDOE) be notified, in writing, of the intent to conduct treatability studies no less than 45 days prior to conducting the studies. Treatment of actual waste in the test apparatus shall not proceed unless such a notice compliant with WAC 173-303-071(s)(I) is submitted (WDOE 1994). Compliance with this constraint has been met with treatability test notification for ion exchange (Izatt et al. 1988).

ALARA principles shall guide all actions in this test. 


\subsection{WASTE MANAGEMENT AND DISPOSAL}

Wastes from the conduct of this test scope will include extraction media, extraction columns, sample bottles, feed beakers, Tygon ${ }^{2}$ tubing, valves, waste liquor, and treatment effluent. All materials having contacted the tank waste liquor must be considered mixed wastes as the tank wastes have been designated to contain F-listed solvents (EPA 1986). To the greatest extent possible, bottles containing wastes brought into the hot cell will be of polyethylene so that they may be melted down within the cell following use. The extraction media will be dissolved, sampled, and sent to the tank farm. Excess and spent samples, and undispositioned effluent will be disposed in accordance with accepted 222-S laboratory procedures. The liquid material will be sent back using the transfer line from 222-S laboratory to the tank farms. This should occur by June of 1997 , pending the availability of the transfer line. Glass vessels will be rinsed, broken (if required), packaged as mixed waste, and removed from the cell for appropriate waste disposal.

Although there has been some consideration for further application of the extraction media, preliminary dose models (Hendrickson and Duncan 1996) indicate that shielding sufficient to reduce dose to the 222-S laboratory administrative requirement of $10 \mathrm{mR} / \mathrm{hr}$ would exceed the $18 \mathrm{~kg}$ capacity of the cell manipulators. As such, it cannot be considered safe to remove these materials from the hot cell intact.

\subsection{EXPECTED RESULTS}

This test will demonstrate the cesium selectivity and load capacity of CST using actual Hanford saltcake waste. This information will be compared to similar data gathered using simulants and will be used to validate the simulant data's use in the designing of a cesium removal pretreatment process.

Success of these tests will be in the form of chemical analysis and automatic beta/gamma sample counts demonstrating rise in concentration of the effluent cesium beyond $50 \%$ of inlet concentration (breakthrough, $\lambda_{50}$ ) such that the number of column volumes processed at breakthrough be determinable on a constant slope.

Prior development of these sorption materials indicates that throughput expectations, for saltcake wastes treated with CST, may vary from slightly less than a thousand to several thousand column volumes of waste feed to achieve a $\lambda_{50}$. Due to the wide range of these expectations, on-line beta-gamma detection capability will be required to ensure adequate sampling to describe the effluent profile.

2 Tygon is a trademark of Norton Performance Plastics, Akron, $\mathrm{OH}$. 


\subsection{TEST PROCEDURE}

The content of the test procedure being developed is summarized here. The test procedure is partitioned into three primary subdivisions: system acceptance testing and calibration; crystalline silicotitanate test run preparation and loading; system flush, decontamination, and waste management. Sampling procedures are a component of each of these subdivisions of the test and are provided as a fourth component of the test.

Laboratory instruction, as necessary, will be developed to implement these laboratory 222-S procedures.

Initial pump calibration and subassembly IX material conditioning will be conducted in nonradiologically contaminated conditions. Thus portions of test conduct through conditioning will be conducted in parallel prior to hot cell entry of the assembly. Subsequent work will be conducted in the sequence specified by the procedure document.

System acceptance testing and calibration procedures include, reagent acquisition, exchange material dissolution, beta-gamma probe calibration, equipment assembly, and flow and leak testing. Reagents to be used in the test work will be acquired from laboratory stores; their specifications will be provided in the procedures. Calibration procedures for the on-line Beta-Gamma probe are defined to ensure appropriate physical sampling breakthrough. Procedures are similarly established for nonradiological assembly, flow tests and leak tests.

The CST test preparation and run is supported with procedures for pump flow rate measurement, exchange column conditioning with sodium hydroxide, waste feed preparation, system flush with sodium hydroxide, test run to an expectation of approximately 1,200 column volumes $(-3.2 \mathrm{~L})$ at 6 column volumes per hour while sampling the primary column effluent on a variable frequency (sample/100CV through $500 \mathrm{CV}$ followed by sample/50CV) and composite effluent sampling. Waste feed procedures detail batch preparation of waste feed by solubilization with approximately $0.75 \underline{\mathrm{M} \mathrm{NaOH}}$, mixing, settling, filtration or centrifugation as needed and sample acquisition. Further procedures detail system flush with sodium hydroxide. Although elution is not planned it may be necessary for the removal of TRU components to facilitate appropriate waste disposal.

System clean out and waste management procedures detail handling of thermolabile wastes, handling of exchange columns and digestion of resins, disposition of liquors (tank waste, waste feed, rinses, flushes, eluates, effluents, and unspent samples), and disposal of other solid wastes. It is intended that much of the test effluent will be reserved and shipped by PNNL to their laboratory facilities for further EM-50 work in the development and deployment of technetium ion exchange materials or processes. 
Sample analyses detailed include chemical and radiochemical analyses of waste feed batches, primary, and secondary column effluent and composite (post guard column) effluent samples, and dissolved IX materials. Analytical methods, dependent upon need, matrix and funding, are planned to include inductively coupled plasma mass spectroscopy (ICP-MS), inductively coupled plasma-atomic emission spectroscopy (ICP-AES), gamma energy analysis (GEA), total alpha analysis, beta scintillation (Tc), $\mathrm{OH}^{-}$specific ion electrode (SIE) analysis, suspended solids, and TOC.

\subsection{SAFETY}

Because the waste material to be used in this test could yield significant radiation doses if mishandled, the material will be remotely handled, shipped in shielded containers, and tested in hot cell environments.

Dose analyses conducted under (Hendrickson and Duncan 1996) strongly suggested that high load exchange columns not be considered for removal from the hot cell and supported that contention by estimating required shielding masses beyond manipulator capacity. Hence, the continued handling of such column material will be through digestion and disposal to the tank farms.

In addition, radiation work in loading tank liquor between cells indicates that strong precautions should be used when handling large volumes of unshielded tank liquors.

Dependent upon receipt form of the tank liquor, the radiation work permit must be supported with dose assessments if the liquor or saltcake is transferred between cells. Standard current laboratory radiation work procedures will apply if not superseded.

Material Safety Data Sheets regarding appropriate handling and response for reagents used in the test conduct will be provided in the test procedure.

\subsection{QUALITY ASSURANCE}

Quality assurance requirements are guided by 10 CFR 830.120 Quality Assurance Requirements (DOE 1994a) and by the Implementation Guide for Use with 10 CFR 830.120 (DOE 1994b). The implementation of 10 CFR 830.120 is through the Quality Assurance Manual (WHC 1996) and facility specific quality assurance plans.

Existent quality assurance requirements encompassed by the Quality Assurance Plan (Meznarich 1995) of the laboratory facilities will be met in the conduct of this work and its chemical analysis. The quality assurance for the conduct of the unit operations and hot cell 
activities will be in accordance with the approved process testing quality assurance plan (Meznarich 1996).

Further details of quality assurance, as required, shall be contained within the test procedures.

\subsection{ORGANIZATION AND FUNCTION RESPONSIBILITIES}

Lead staff on this task are with SESC's Process Engineering organization (PE) managed by James A. Hunter. PE staff anticipated to be involved with this task include the Principal Investigator, Douglas W. Hendrickson, Rabindra K. Biyani, P.E., and Dr. James B. Duncan.

Douglas W. Hendrickson is a Principal Engineer. Mr. Hendrickson has been active in the sampling, characterization, and pretreatment and treatment of Hanford tank wastes. Recent duties have included those of Principal Investigator for Hanford Tank Waste Cesium Removal Test (EM-50 funded), Plasma Calcination of Hanford Waste (EM-30 and EM-50 funded), Principal Investigator for Supercritical Carbon Dioxide Extraction of Solid Mixed Wastes (EM-50 funded), pretreatment application reviews, and Project Engineer for Plasma Arc Vitrification of Hanford Low Level Waste.

Rabindra K. Biyani is a Principal Engineer. Mr. Biyani provided support for the conduct of the EM-50 funded Hanford tank waste cesium removal test and its report writing. He was the cognizant engineer in the treatability study on 183-H Basin sludge waste and was active in the evaluation of the effect of organics in the performance of Hanford grout. He has performed scoping studies for an emergency IX system, for the removal of cesium in the Waste Encapsulation and Storage Facility storage pools, in case of a cesium capsule failure.

Dr. James B. Duncan is a Principal Engineer. Dr. Duncan has been active in the area of waste treatment to include radiolysis of recalcitrant organics, water filtration and treatment of radioactive contaminated waters, and cognizant engineer for the treatability tests for the 100-HR-3 groundwater remediation. Recently he has been active in a program for the membrane mediated separation of tritiated water from water and is a coinventor of the process used in that effort.

Scientists and chemical technicians at Hanford's 222-S Laboratory facilities will be involved in establishing test procedures, operating the test equipment and running the test. Scientific staff anticipated to participate in this task includes Senior Scientist Mark A. Beck. Mr. Beck is a radiochemist with extensive experience in handling Hanford Site wastes and detection equipment development (Beck et al. 1996). Mr. Beck also has considerable experience in designing and conducting radioactive ion exchange tests including 100-HR-3 bench scale 
proof tests, Waste Sampling and Characterization Facility emergency cesium and strontium removal, and previous CST cesium removal tests.

PNNL has performed a great deal of work on cesium removal and will be responsible for funding and managing this project's work scope. They will have approval authority for the test plan, test procedures, and test report and will ensure that this cesium removal test is performed and results presented in a manner that allow comparison with previous simulant work. PNNL scientists involved with this support will include Dean E. Kurath.

The support and consultation of CST developers and the manufacturer has been and will be used as necessary in this test conduct. Such support may be provided by Mr. Dennis Fennelly of UOP, Mr. James Miller of SNL, Dr. Raymond G. Anthony of Texas A\&M University, and Dr. Norman E. Brown, formerly of SNL.

\subsection{SCHEDULE}

A detailed schedule of activities is depicted in Figure 2 and milestone activities are listed in Table 4. Manpower and detailed costs were provided in a Technical Task Plan provided to

Table 4: Milestone Summary

\begin{tabular}{|c|l|c|c|}
\hline Task & \multicolumn{1}{|c|}{ Work Element / Milestone } & Level & Date \\
\hline 15 & Acquire Waste & 00 & $11 / 12 / 96$ \\
\hline 16 & Complete Waste Feed Analysis & 00 & $12 / 18 / 96$ \\
\hline 17 & Acquire Equipment & 00 & $11 / 22 / 96$ \\
\hline 18 & Test Plan Issuance & PNNL & $11 / 21 / 96$ \\
\hline 19 & Test Procedure Issuance & PNNL & $12 / 09 / 96$ \\
\hline 20 & Test Apparatus and Waste Installation & 00 & $01 / 21 / 97$ \\
\hline 21 & Test Conduct Completed & PNNL & $03 / 17 / 97$ \\
\hline 22 & Test Report Issued & 00 & $06 / 20 / 97$ \\
\hline 31 & Waste Loadout and Decontamination & 00 & $06 / 30 / 97$ \\
\hline
\end{tabular}


EM-50 prior to work initiation. At final reporting, a detail of manpower and costs will be

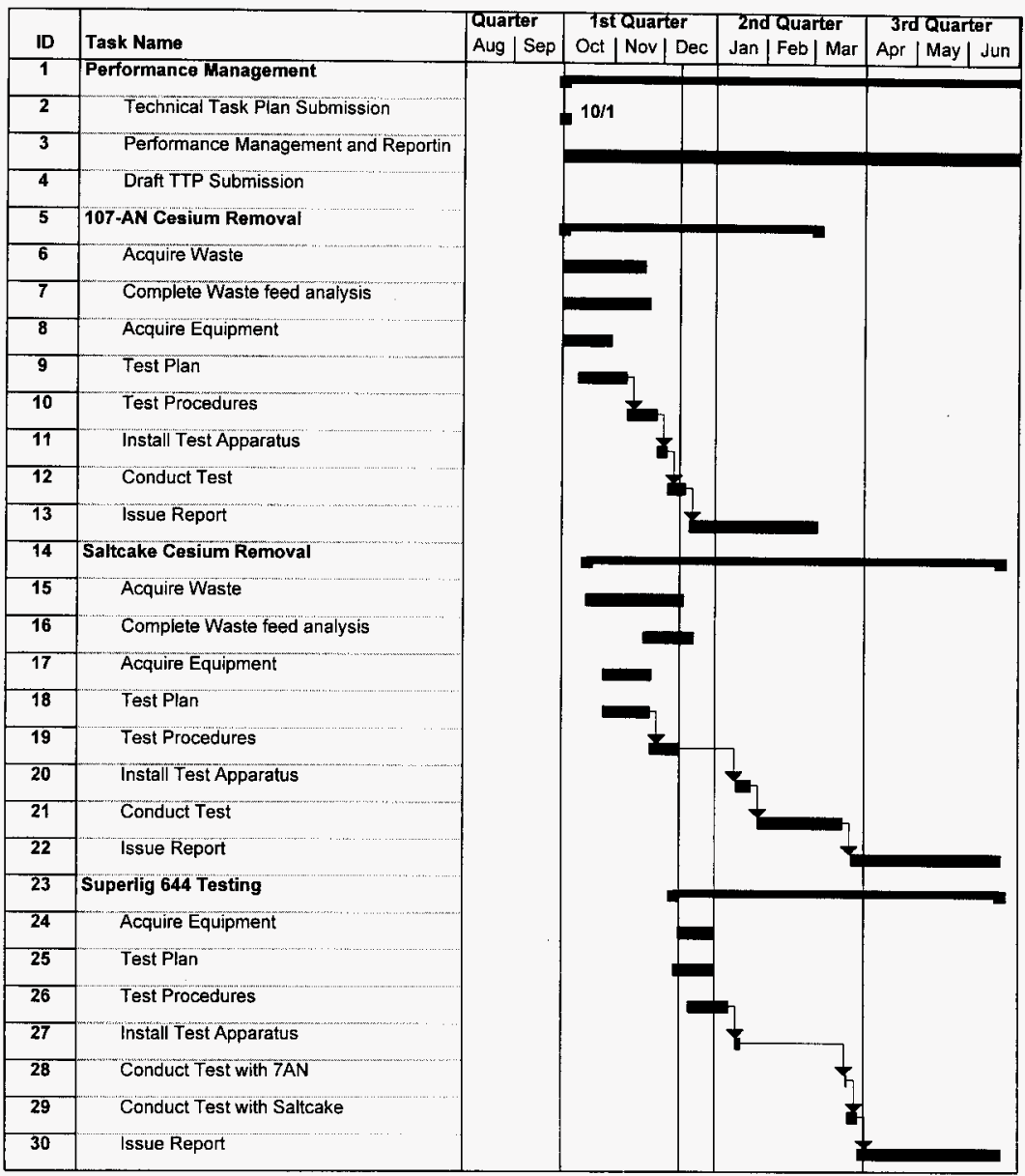

Figure 2: Cesium Removal Task Schedule accumulated. 


\subsection{REPORTS}

The final test report for this task will address the performance of the CST sorbent. It will compare the CST sorbent's performance with actual waste to their performance with simulants in previous tests. It will also compare CST performance with saltcake waste against CST performance with DSSF and CC wastes evaluated in previous and planned tests (Hendrickson, Biyani, and Beck 1996; Hendrickson, Biyani, and Duncan 1996). The report will be a supporting document prepared for public release.

This report will be fed back to the Tank Focus Area and other EM-50 contributors who have been developing and testing cesium sorbents. The end user for this and other work on cesium removal is DOE's EM-30 funded organizations who are developing the pretreatment options for Hanford and other DOE sites. The final report will also be provided to these organizations.

\subsection{DATA SHEETS}

System assembly, waste feed preparation, system operation, and sample collection will be recorded on check sheets and data sheets in forms to be developed as a part of the test procedures. These data will be recorded into appropriate test logs. Digitally recorded data will be captured, stored on electronic media, printed to a hard copy for retention in the test $\log$, and appended to the final report. Sample analyses returned from chemical or radiochemical assay, will be stored in the laboratory information management system (LabCore) and appended to the final report.

\subsection{REFERENCES}

Barney, G. S., 1976, Vapor-Liquid-Solid Phase Equilibria of Radioactive Sodium Salt Wastes at Hanford, ARH-ST-133, Atlantic Richfield Hanford Company, Richland, Washington, January 1976.

Beck, M. A., R. S. Addleman, G. R. Blewett, E. R. Selle, C. S. McClellan, D. A. Dodd, G. L. Troyer, and B. D. Keele, 1996, Remote Nuclear Screening System for Hostile Environments, WHC-SD-WM-DTR-039, Rev. 0, Westinghouse Hanford Company, Richland, Washington, February 27, 1996. 
Brown, G. N., L. A. Bray, C. D. Carlson, K. J. Carson, J. R. DesChane, R. J. Elovich, F. V. Hoopes, D. E. Kurath, L. L. Nenninger, P. K. Tanaka, 1996, Comparison of Organic and Inorganic Ion Exchangers for Removal of Cesium and Strontium from Simulated and Actual Hanford 241-AW-101 DSSF Tank Waste, PNL-10920, Battelle Pacific Northwest Laboratory, Richland, Washington, January 1996.

DOE, 1994a, Nuclear Safety Management, "Quality Assurance Requirements," 10 CFR 830.120, U. S. Department of Energy, Washington D.C., April 5, 1994.

DOE, 1994b, Implementation Guide for Use with 10 CFR 830.120 Quality Assurance, G-830.120-Rev. 0, U. S. Department of Energy, Washington D.C., April 15, 1994.

DOE, 1996, REQUEST FOR PROPOSALS (RFP) NO. DE-RP06-96RL13308 [TWRS Privatization], Richland, Washington, February 20, 1996.

EPA, 1986, 40 CFR $\$ 261.31$, Hazardous wastes from non-specific sources, U. S. Environmental Protection Agency, Washington, D.C., August 25, 1986.

Hendrickson, D. W., and J. B. Duncan, 1996, Hanford Tank Waste Supernatant Cesium Removal Test Plan, WHC-SD-RE-TP-022, Rev. 0, Westinghouse Hanford Company, Richland, Washington, May 31, 1996.

Hendrickson, D. W., R. K. Biyani, and M. A. Beck 1996, Hanford Tank Waste Supernatant Cesium Removal Test Report, WHC-SD-RE-TRP-018, Rev. 0A, Westinghouse Hanford Company, Richland, Washington, October 1, 1996.

Hendrickson, D. W., R. K. Biyani, and J. B. Duncan, 1996, Hanford Complexant Concentrate Supernatant Cesium Removal Test Plan, WHC-SD-RE-TP-023, Rev. 0, SGN Eurisys Services Company, Richland, Washington, November 8, 1996.

Izatt, R. D., T. D. Chikalla, and R. E. Lerch, 1988, "Notification of Intent to Perform Treatability Tests Exclusive of Resource Conservation and Recovery Act (RCRA) Subtitle (53 Federal Register 27290-27302)," Letter, U. S. DOE, Richland, Operations Office to Mr. Tom Eaton, State of Washington, Department of Ecology, November 9, 1988.

Marinsky, J. A., and Y. Marcus, 1995, Ion Exchange and Solvent Extraction, Vol. 12, (Chapter 9, Mitsou Abe, "Ion-Exchange Selectivities of Inorganic Ion Exchangers"), Marcel Dekker, Inc., New York, New York. 
Meznarich, H. K., 1995, 222-S Laboratory Quality Assurance Plan, WHC-SD-CP-QAPP-016, Rev. 0, Westinghouse Hanford Company, Richland, Washington, July 31, 1995.

Meznarich, H. K., 1996, 222-S Process and Development Laboratory Quality Assurance Plan, WHC-SD-CP-QAPP-018, Rev. 0, Westinghouse Hanford Company, Richland, Washington, June 1996.

NRC, 1989, Title 10 Code of Federal Regulations, Part 61, Licensing Requirements for Land Disposal of Radioactive Waste, Nuclear Regulatory Agency, Washington, D.C., May $25,1989$.

WDOE, 1994, Washington Administrative Code, Chapter 173-303, Dangerous Waste Regulations, (WAC 173-303), Washington Department of Ecology, Olympia, Washington, January 8, 1994.

WHC, 1995, Standard Engineering Practices, Engineering Practice 4.2, "Testing Requirements," WHC-CM-6-1, Westinghouse Hanford Company, Richland, Washington.

WHC, 1996, Quality Assurance Manual, WHC-CM-4-2, Westinghouse Hanford Company, Richland, Washington. 
DISTRIBUTION SHEET

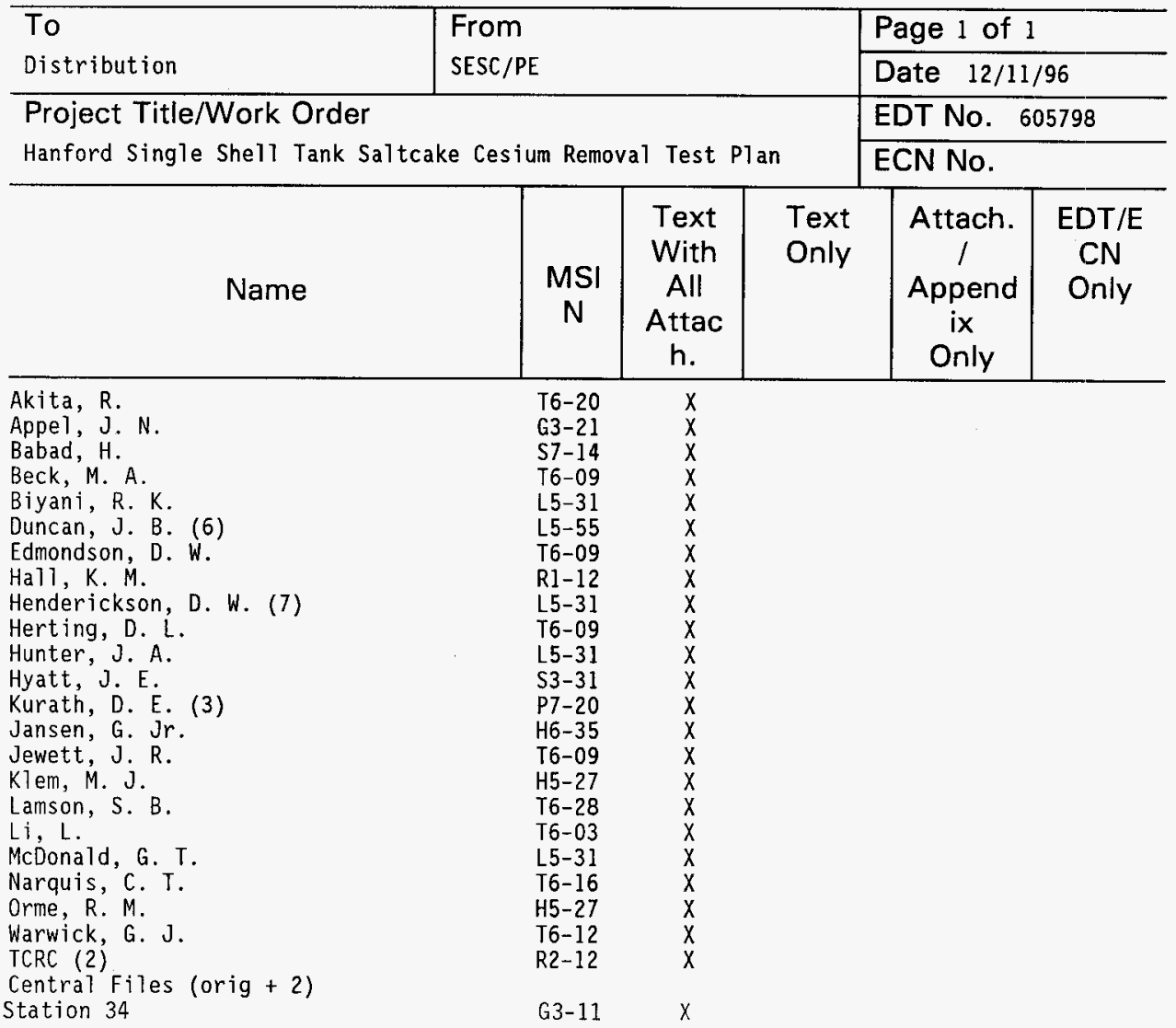

